СОЦІАЛЬНО-ЕКОНОМІЧНИЙ РОЗВИТОК

ТА ІНВЕСТИЦІЙНО-ІННОВАЦІЙНА ДІЯЛЬНІСТЬ СУБ'ЄКТІВ ГОСПОДАРЮВАННЯ НА ПРИКЛАДІ ПРИЧОРНОМОРСЬКОГО РЕГІОНУ УКРАЇНИ

\title{
SOCIO-ECONOMIC DEVELOPMENT \\ AND INVESTMENT INNOVATIVE ACTIVITY OF BUSINESS ENTITIES ON THE EXAMPLE OF THE BLACK SEA REGION OF UKRAINE
}

УДК 658. 33

https://doi.org/10.32843/bses.64-3

\section{Кулаков О.О.}

к.е.н.,

головний спеціаліст

відділу міжнародного

та міжрегіонального співробітництва

управління зовнішньоекономічних

відносин департаменту інвестиційно-

інноваційного розвитку

і зовнішніх відносин

Донецької обласної

державної адміністрації

Kulakov Oleksii

Donetsk Regional State Administration
Різні країни інвестують в українську економіку завдяки інвестуванню в регіональні програми розвитку, різні підприємства тощо. Інвестиції розвивають українську економіку через поліпшення економічного середовища, оновлення інфраструктури, удосконалення органів державної влади, покращення гуманітарної ситуації, підтримання малого та середнього підприємництва, впровадження ресурсо- та енергозберігаючих технологій, зміцнення прав людини, підвищення кваліфокації працівників тощо. Украй важливою $\epsilon$ активізація іноземного інвестування у Причорноморському (Південному) регіоні. Проведене дослідження показує важливість фіскальної децентралізації, що часто слабка або навіть відсутня ланка децентралізації. Однією з найпоширеніших проблем фріскальної децентралізації $\epsilon$ невідповідність обов'язків, покладених на місцеві органи влади, та ресурсів, доступних місцевим органам влади. Отже, добре організована система фріскальної децентралізації є життєво важливою для успіху процесу децентралізації.

Ключові слова: інвестиції, інвестиційна привабливість, прямі іноземні інвестиції, капітальні інвестиції, Причорноморський регіон, валовий регіональний продукт, програма «Басейн Чорного моря».

Разные страны инвестируют в украинскую экономику благодаря инвестированию в региональные программы развития, различные предприятия и тому подобное Инвестиции развивают украинскую экономику через улучшение экономической среды, обновление инорраструктуры, совершенствование органов государственной власти, улучшение гуманитарной ситуации, поддержание малого и среднего бизнеса, внедрение ресурсо- и энергосберегающих технологий, укрепление прав человека, повышение квалификации работников и тому подобное. Крайне важна активизация иностранного инвестирования в Причерноморском (Южном) регионе. Проведенное исследование показывает важность фискальной децентрализации как слабого или даже отсутствующего звена децентрализации. Одной из самых распространенных проблем ффискальной децентрализации является несоответствие обязанностей, возложенных на местные органы власти, u ресурсов, доступных для местных органов власти. Хорошо организованная система фискальной децентрализации является жизненно важной для успеха процесса децентрализации.

Ключевые слова: инвестиции, инвести ционная привлекательность, прямые иностранные инвестиции, капитальные инвестиции, Причерноморский регион, валовой региональный продукт, программа «Бассейн Черного моря».

Different countries invest in the Ukrainian economy by investing in regional development programs, various enterprises and so on. Investments develop the Ukrainian economy by improving the economic environment, upgrading infrastructure, improving public authorities, improving the humanitarian situation, supporting small and medium-sized enterprises, introducing resource and energy-saving technologies, strengthening human rights, training workers and more. It is extremely important to intensify foreign investment in the Black Sea (southern) Region. The study shows the importance of fiscal decentralization, which is often a weak or even absent link of decentralization. One of the most common problems of fiscal decentralization is the mismatch between the responsibilities of local governments and the resources available to local governments. Thus, a well-organized system of fiscal decentralization is vital to the success of the decentralization process. It was found that most foreign direct investment in Donetsk and Odessa regions, which indicates the development of investment attractiveness of the Black Sea region of Ukraine. But in the Mykolaiv and Kherson regions there are less direct foreign investments that needs increase of investment attractiveness of the Black Sea Region of Ukraine. It is analyzed that the best indicators of capital investment in Donetsk and Odessa regions, which indicate the attraction of capital investment in the economy of the Black Sea Region of Ukraine. In Mykolaiv and Kherson oblasts there are small volumes of capital investments, which demonstrate insufficient investment efficiency and it is necessary to increase the efficiency of investment projects implementation. It is investigated that the best indicators of gross regional product in Donetsk and Odessa regions, which show the development of the economy of the Black Sea region of Ukraine. In Mykolaiv and Kherson regions, the volumes of gross regional product are smaller, which show insufficient economic development and it is necessary to support small and medium business, attract new foreign investments, raise the image of the Black Sea Region of Ukraine, etc.

Key words: investments, investment attractiveness, foreign direct investment, capital investment, Black Sea Region, gross regional product, Black Sea Basin program.

Постановка проблеми. На сучасному етапі розвитку менеджменту суб'єктів господарювання в економіці України існує проблема реалізації інвестиційно-інноваційної діяльності. Різні країни інвестують в українську економіку завдяки інвестуванню в регіональні програми розвитку, різні підприємства тощо. Інвестиції розвивають українську економіку через поліпшення економічного середо- вища, оновлення інфраструктури, удосконалення органів державної влади, покращення гуманітарної ситуації, підтримання малого та середнього підприємництва, впровадження ресурсо- та енергозберігаючих технологій, зміцнення прав людини, підвищення кваліфрікації працівників тощо. Украй важливою $є$ активізація іноземного інвестування у Причорноморському (Південному) регіоні, а саме 
в Одеській, Миколаївській, Херсонській та Донецькій областях, адже всі ці області беруть участь у програмі «Басейн Чорного моря». Тому актуальності набувають сучасні проблеми менеджменту суб'єктів господарювання в контексті інвестиційно-інноваційної діяльності в економіці України, дослідження цих проблем допоможе підвищенню інвестиційної привабливості України та її регіонів. Розвиток та вдосконалення іноземного інвестування сприятиме економічному розвитку України.

Аналіз останніх досліджень і публікацій. Проблемам соціально-економічного розвитку та інвестиційно-інноваційної діяльності суб'єктів господарювання присвячено низку публікацій вітчизняних учених-економістів. О. Кальченко у своїх працях досліджував теоретичні аспекти фрормування механізму управління фрінансовою стійкістю підприємства [1, с. 321]. А.М. Апаров розглядає у своїх працях актуальні проблеми захисту ділової репутації суб'єктів господарювання в Україні [2, с. 4]. У дослідженнях Е. Соколової приділено увагу проблемам управління ліквідністю та платоспроможністю підприємства [3, с. 331]. У працях B.M. Швайдак досліджено пріоритетні напрями інвестування інноваційної діяльності в Україні [4, с. 101]. Л.М. Киш висвітлює стратегічне управління як основну частину менеджменту підприємства в Причорноморському регіоні України [5, с. 108]. У дослідженнях Н.М. Хорунжак приділяється увага обліку в умовах цифрової економіки, проблемам і перспективам у Причорноморському регіоні України [6, с. 176]. О.В. Манойленко аналізує моделювання розвитку взаємодії державного та приватного секторів в інноваційно-інвестиційній сорері в Причорноморському регіоні України [7, с. 168]. І.Б. Стенічева досліджує інноваційний потенціал як чинник розвитку регіональних соціально-економічних систем у Причорноморському регіоні України [8, с. 120]. В.І. Аранчій розглядає стратегічні напрями інвестиційно-інноваційного розвитку аграрного виробництва на галузевому та господарському рівнях у Причорноморському регіоні України [9, с. 34]. Відзначаючи вагомий внесок вітчизняних учених-економістів у розвинення питань теорії та практики сучасних проблем менеджменту суб'єктів господарювання, слід зауважити, що недостатньо досліджено сучасні проблеми менеджменту суб'єктів господарювання в контексті інвестиційно-інноваційної діяльності в економіці України.

Постановка завдання. Метою дослідження $€$ аналіз сучасних проблем менеджменту суб'єктів господарювання в контексті інвестиційно-інноваційної діяльності на прикладі Причорноморського регіону України.

Виклад основного матеріалу дослідження. Необхідно дослідити основні показники розвитку Причорноморського регіону України для аналізу сучасних проблем менеджменту суб'єктів господарювання в контексті інвестиційно-інноваційної діяльності. Проаналізуємо обсяги прямих іноземних інвестицій в економіці Причорноморського регіону України (табл. 1).

Як видно з табл. 1, найбільше прямих іноземних інвестицій - у Донецькій та Одеській областях, що свідчить про розвиток інвестиційної привабливості Причорноморського регіону України. Але в Миколаївській та Херсонській областях менше прямих іноземних інвестицій, що потребує підвищення інвестиційної привабливості Причорноморського регіону.

Таблиця 1

\section{Прямі іноземні інвестиції у середньому на одну громаду в економіці \\ Причорноморського регіону України, 2020 р. (млн дол. США)}

\begin{tabular}{|c|l|c|}
\hline № & \multicolumn{1}{|c|}{ Показники } & $\mathbf{2 0 2 0}$ рік \\
\hline 1 & Донецька область & 39,3 \\
\hline 2 & Миколаївська область & 7,2 \\
\hline 3 & Одеська область & 12,3 \\
\hline 4 & Херсонська область & 3,3 \\
\hline
\end{tabular}

Джерело: розраховано за даними статистики [11; 12]

Проаналізуємо капітальні інвестиції у середньому на одну громаду в економіці Причорноморського регіону України (рис. 1).

Як видно з рис. 1, найкращі показники капітальних інвестицій - у Донецькій та Одеській областях, що свідчить про залучення капітальних інвестицій в економіку Причорноморського регіону України. У Миколаївській та Херсонській областях невеликі обсяги капітальних інвестицій, що демонструє недостатню ефективність інвестування. Необхідно підвищувати ефективність упровадження інвестиційних проєктів.

Дані інвестування в Причорноморському регіоні України не показують економічного розвитку областей. Потрібно проаналізувати дані, що відображають валовий регіональний продукт (ВРП) у середньому на одну громаду в економіці Причорноморського регіону України (рис. 2).

Як видно з рис. 2, найкращі показники ВРП у Донецькій та Одеській областях, що показує розвиток економіки Причорноморського регіону України. У Миколаївській та Херсонській областях менші обсяги ВРП, що показує недостатній економічний розвиток. Необхідно підтримувати малий та середній бізнес у Причорноморському регіоні України, залучати нові іноземні інвестиції, підвищувати імідж регіону тощо.

У результаті аналізу основних показників розвитку Причорноморського регіону України виявлено, що необхідно вирішувати сучасні проблеми менеджменту суб'єктів господарювання в контексті інвестиційно-інноваційної діяльності. 


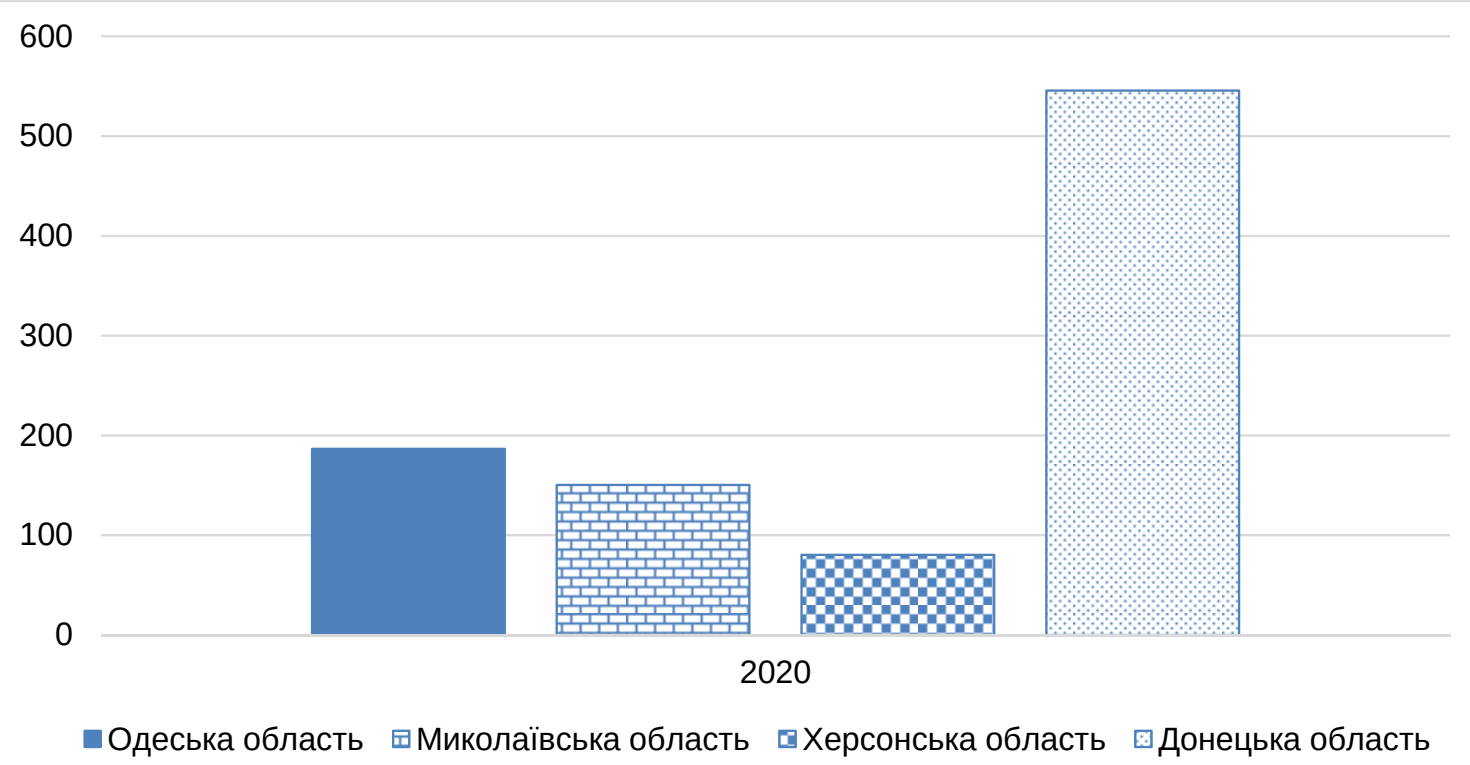

Рис. 1. Капітальні інвестиції у середньому на одну громаду в економіці Причорноморського регіону України (млн грн)

Джерело: розраховано за даними статистики [10; 12]

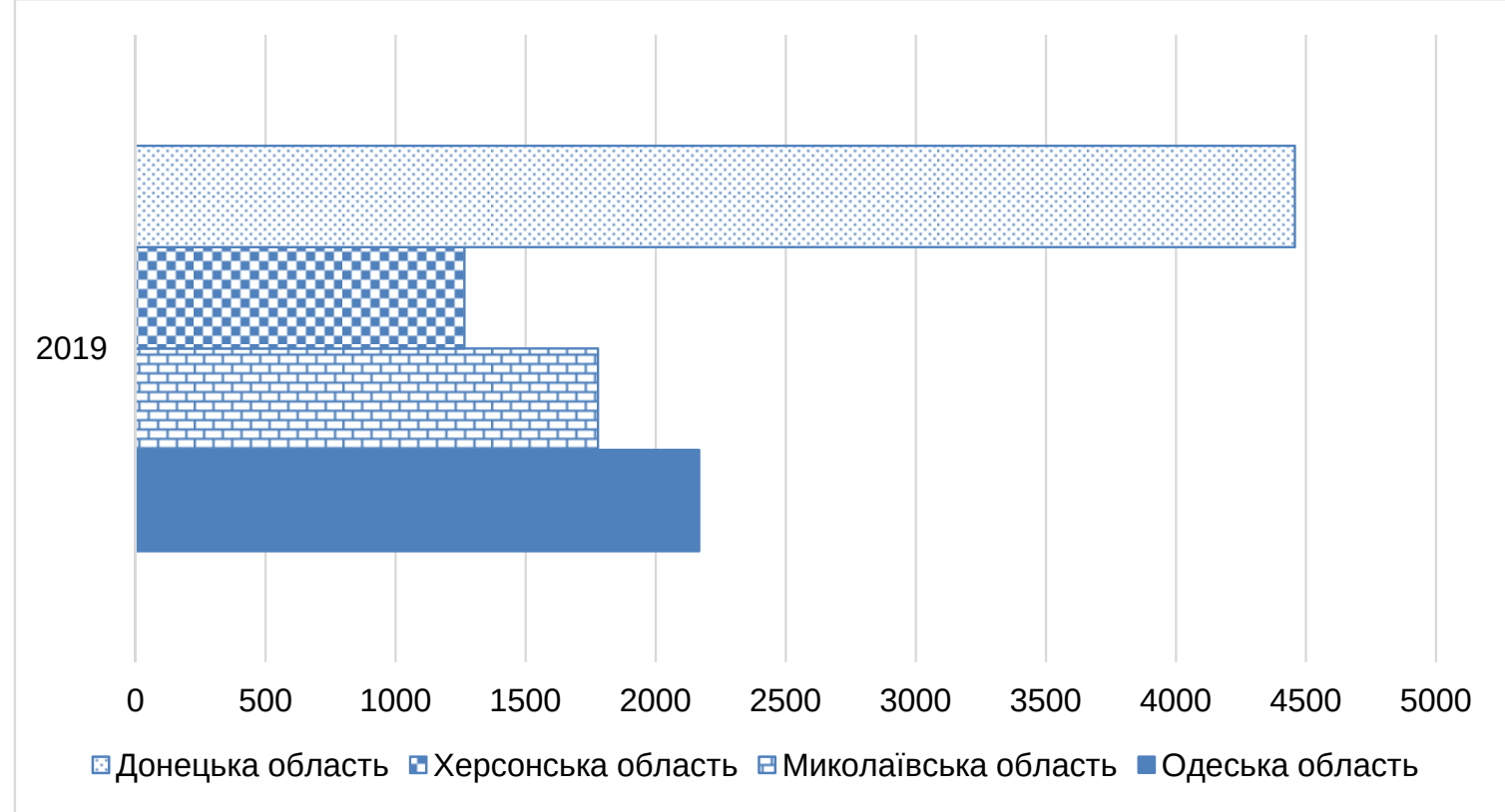

Рис. 2. ВРП у середньому на одну громаду в економіці Причорноморського регіону України (млн грн)

Джерело: розраховано за даними статистики [10; 12]

Основою менеджменту суб'єктів господарювання на основі інвестиційно-інноваційної діяльності повинна бути фріскальна децентралізація. Фіскальна децентралізація відповідає принципу, що «гроші йдуть за функцією». Це означає, що коли вищі органи влади доручають місцевим органам влади нові завдання, вищі органи влади також повинні забезпечити необхідні ресурси.
Фіскальна децентралізація має чотири стовпи: розподіл витрат, розподіл доходу, міжурядові трансфрерти, а також управління запозиченнями та боргом (рис. 3). Децентралізація включає економічні та фрінансові критерії, які мають велике значення для результатів розвитку, яким сприяє децентралізація. Місцеві органи влади вважають фрорму розподілу державних ресурсів недосконалою. Вищі органи влади стверджують про відсутність інтересу 


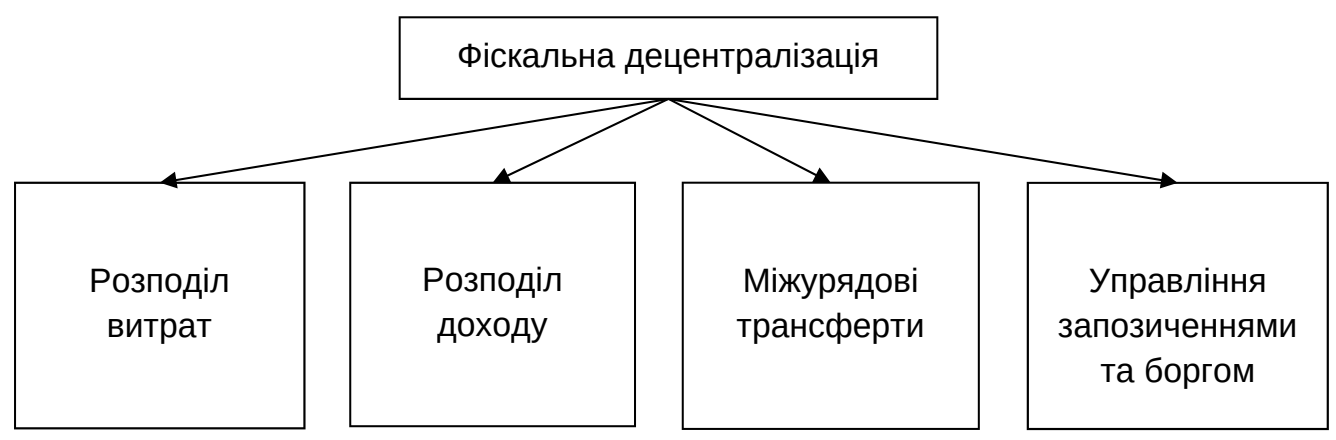

Рис. 3. Чотири стовпи фріскальної децентралізації

Джерело: власна розробка автора

та готовності збирати місцеві доходи як провідну причину фінансових проблем децентралізації.

Метою є добре розроблена система фріскальної децентралізації з динамічною міжурядовою структурою класифікації видатків та відповідальністю за фрінансування, що сприяють справедливості, есрективності та балансу макроекономічних показників. Однак найменш розвинений аспект процесів децентралізації в більшості країн - це фріскальна децентралізація. Як правило, вищі органи влади передають обов'язки, а не ресурси.

Перший стовп розподіл витрат передбачає передачу відповідальності за витрати на нижчі рівні управління. Важливим чинником у визначенні типу фріскальної децентралізації $є$ аналіз розподілу фрункцій між рівнями управління. Застосовуючи принцип, що «гроші йдуть за фрункцією», розподіл видатків тісно корелює з делегованими фрункціями місцевих органів влади.

Розподіл видаткових обов'язків може базуватися на різних економічних показниках та ефективності, наприклад аналіз витрат і вигід, близькість до бенефіціарів та інші переваги.

Важливим елементом, який необхідно враховувати під час розподілу витрат, є підзвітність. Коли видатки місцевих органів влади пов'язані з місцевими джерелами доходу, існує велика ймовірність того, що місцеві органи влади діятимуть більш відповідально та громадяни матимуть більший інтерес у здійсненні контролю над витратами.

Другий стовп фріскальної децентралізації - розподіл доходу. Після розподілу відповідальності між рівнями управління другим етапом $€$ визначення джерела фрінансування бюджетів. Потенціал для збору власних доходів має вирішальне значення для оцінки управління, вимірювання автономії, підзвітності та самостійності місцевих органів влади, тому місцеві податки, збори та інші місцеві доходи відіграють фрундаментальну роль у поєднанні очікувань та потреб громадян.

Розуміння відносин між владою та громадянами має вирішальне значення для поліпшення доходів місцевого рівня. Громадяни платять податки, щоб користуватися суспільними благами та послугами.
Чим вищі податки громадян, тим більше і кращих благ та послуг громадяни очікують.

Третій стовп фріскальної децентралізації - міжурядові трансорерти. У процесі децентралізації однією з основних фрункцій вищих органів влади є сприяння справедливості та перерозподілу багатства по всій країні. Ці цілі досягаються за допомогою міжурядових трансорертів. Система міжурядових трансорертів полягає у забезпеченні всіх жителів країни незалежно від місця їх проживання та рівня доходу основними благами та послугами.

Висновки 3 проведеного дослідження. Проведене дослідження показує важливість фріскальної децентралізації, яка часто слабка або навіть відсутня. Однією з найпоширеніших проблем фріскальної децентралізації $€$ невідповідність обов'язків, покладених на місцеві органи влади, та ресурсів, доступних для місцевих органів влади. Отже, добре організована система фріскальної децентралізації $€$ життєво важливою для успіху процесу децентралізації. Виявлено, що найбільше прямих іноземних інвестицій - у Донецькій та Одеській областях, що свідчить про розвиток інвестиційної привабливості Причорноморського регіону України. Але в Миколаївській та Херсонській областях менше прямих іноземних інвестицій, що потребує підвищення інвестиційної привабливості Причорноморського регіону України. Проаналізовано, що найкращі показники капітальних інвестицій - у Донецькій та Одеській областях, що свідчить про залучення капітальних інвестицій в економіку Причорноморського регіону України. У Миколаївській та Херсонській областях невеликі обсяги капітальних інвестицій, що демонструє недостатню есрективність інвестування, та необхідно підвищувати ефективність впровадження інвестиційних проєктів. Досліджено, що найкращі показники ВРП - у Донецькій та Одеській областях, які показують розвиток економіки Причорноморського регіону України. У Миколаївській та Херсонській областях менші обсяги ВРП, що показує недостатній економічний розвиток, і необхідно підтримувати малий та середній бізнес, залучати нові іноземні інвестиції, підвищувати імідж Причорноморського регіону України тощо. 


\section{БІБЛІОГРАФІЧНИЙ СПИСОК:}

1. Кальченко О. Теоретичні аспекти орормування механізму управління фрінансовою стійкістю підприємства. Проблеми і перспективи економіки та управління. 2016. № 2. С. 320-326.

2. Апаров А.М., Лобченко В.В. Актуальні проблеми захисту ділової репутації суб'єктів господарювання в Україні. Право та державне управління. 2016. № 1. C. 3-9.

3. Соколова Е., Чернявська Г. Проблеми управління ліквідністю та платоспроможністю підприємства. Збірник наукових праць Державного економікотехнологічного університету транспорту. Серія «Економіка і управління». 2016. № 35. С. 330-338.

4. Швайдак В.М. Пріоритетні напрями інвестування інноваційної діяльності в Україні. Причорноморські економічні студії. 2016. № 12-1. С. 100-104.

5. Киш Л.М. Стратегічне управління, як основна частина менеджменту підприємства. Причорноморські економічні студії. 2019. № 38(1). С. 107-113.

6. Хорунжак Н.М., Лукановська І.Р. Облік в умовах цифрової економіки: проблеми і перспективи. Причорноморські економічні студії. 2019. № 45. С. 175-179.

7. Манойленко О.В., Олійник Ю.А. Моделювання розвитку взаємодії державного та приватного секторів в інноваційно-інвестиційній сфері. Причорноморські економічні студії. 2018. № 27. С. 167-170.

8. Стенічева І.Б. Інноваційний потенціал як чинник розвитку регіональних соціально-економічних систем. Причорноморські економічні студії. 2017. № 13-1. C. 119-123.

9. Аранчій В.І., Зоря О.П., Голбан Т.Т. Стратегічні напрями інвестиційно-інноваційного розвитку аграрного виробництва на галузевому та господарському рівнях. Причорноморські економічні студії. 2019. № 45. С. 33-38.

10. Державна служба статистики України. Київ, 1991. URL: http://www.ukrstat.gov.ua/ (дата звернення: 01.05.2021).

11. Національний банк України. Київ, 1991. URL: https://bank.gov.ua/ua/statistic/sector-external/data-sector-external\#1 (дата звернення: 01.05.2021).

12. Децентралізація в Україні. Київ, 2014. URL: https://decentralization.gov.ua/newgromada?area_id=9 \&region_id=\&otg_type_id=\&year=\&sort_by_squ are=\&sort_by_population=\&sort_by_count $=($ дата звернення: 01.05.2021).

\section{REFERENCES:}

1. Kalchenko O. (2016) Teoretychni aspekty formuvannia mekhanizmu upravlinnia finansovoiu stiikistiu pidpryiemstva [Theoretical aspects of formation of the mechanism of management of financial stability of an enterprise]. Problems and prospects of economics and management, no. 2, pp. 320-326.

2. Aparov A.M., Lobchenko V.V. (2016) Aktualni problemy zakhystu dilovoi reputatsii subiektiv hospodariuvannia $v$ Ukraini [Actual problems of protection of business reputation of business entities in Ukraine]. Pravo ta derzhavne upravlinnia, no. 1, pp. 3-9.

3. Sokolova E., Cherniavska H. (2016) Problemy upravlinnia likvidnistiu ta platospromozhnistiu pidpryiemstva [Problems of liquidity and solvency management of an enterprise]. Zbirnyk naukovykh prats Derzhavnoho universytetu infrastruktury ta tekhnolohii. Seriia : Ekonomika i upravlinnia, no. 35, pp. 330-338.

4. Shvaidak V.M. (2016) Priorytetni napriamy investuvannia innovatsiinoi diialnosti v Ukraini [Priority areas for investing in innovation in Ukraine]. Black Sea Economic Studies, no. 12-1, pp. 100-104.

5. Kysh L.M. (2019) Stratehichne upravlinnia, yak osnovna chastyna menedzhmentu pidpryiemstva [Strategic management as the main part of enterprise management]. Black Sea Economic Studies, no. 38(1), pp. 107-113.

6. Khorunzhak N.M., Lukanovska I.R. (2019) Oblik v umovakh tsyfrovoi ekonomiky: problemy i perspektyvy [Accounting in the digital economy: problems and prospects]. Black Sea Economic Studies, no. 45, pp. 175-179.

7. Manoilenko O.V., Oliinyk Yu.A. (2018) Modeliuvannia rozvytku vzaiemodii derzhavnoho ta pryvatnoho sektoriv $v$ innovatsiino-investytsiinii sferi [Modeling the development of interaction between the public and private sectors in the investment innovative sphere]. Black Sea Economic Studies, no. 27, pp. 167-170.

8. Stenicheva I.B. (2017) Innovatsiinyi potentsial yak chynnyk rozvytku rehionalnykh sotsialno-ekonomichnykh system [Innovative potential as a factor in the development of regional socio-economic systems]. Black Sea Economic Studies, no. 13-1, pp. 119-123.

9. Aranchii V.I., Zoria O.P., Holban T.T. (2019) Stratehichni napriamy investytsiino-innovatsiinoho rozvytku ahrarnoho vyrobnytstva na haluzevomu ta hospodarskomu rivniakh [Strategic areas of investment-innovation development of agricultural production at the industry and economic level]. Black Sea Economic Studies, no. 45 , pp. 33-38.

10. State Statistics Service of Ukraine. Kyiv, 1991. Available at: http://www.ukrstat.gov.ua/ (accessed 01 May 2021).

11. National Bank of Ukraine. Kyiv, 1991. Available at: https://bank.gov.ua/ua/statistic/sector-external/ data-sector-external\#1 (accessed 01 May 2021).

12. Decentralization reform. Kyiv, 2014. Available at: https://decentralization.gov.ua/newgromada?area_id= 9\&region_id=\&otg_type_id=\&year=\&sort_by_square $=\&$ sort_by_population=\&sortcount= (accessed 01 May 2021). 